\title{
海外の屠蓄場および農場を視察後同時発症した $\mathrm{Q}$ 熱患者 3 症例
}

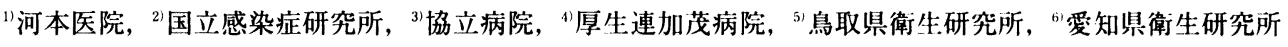 \\ 河本 知秀 ${ }^{1)}$ 小川 基彦 ${ }^{2}$ 岸本 寿男 $^{21}$ 打田 裕-31 \\ 加藤 活大 ${ }^{4)}$ 川本 歩 ${ }^{5}$ 山下 照夫 ${ }^{6)}$
}

(平成 14 年 7 月 1 日受付)

(平成 14 年 8 月 30 日受理)

Key words: Q fever, Coxiella burnetii

\section{序文 \\ $\mathrm{Q}$ 熱はリケッチアの一種 Coxiella burnetii によ} る人獣共通感染症である。ヒトの感染源としては 家畜や愛玩動物が重要で, 主に菌を含む感染動物 の尿, 霬, 胎盤, 羊水などにより污染された環境 中の粉塵やエアロゾールを吸入し感染する.

今回, 海外（オーストラリア・ニュージーラン

ド）の牛の屠蓄場および飼育農場を視察した 3 名 の畜産関係者が, 帰国後ほほ同時に発熱, 全身倦 㤐感を主訴とする $\mathrm{Q}$ 熱を発症した。

本邦では市中肺炎の原因として C. burnetii の関 与が報告されているが1)，いわゆる急性 $\mathrm{Q}$ 熱の典 型的な症状や検査成績に関する報告は少ない223). また今回のように 3 例同時に発症した報告はな く，その臨床経過について報告する.

\section{症例}

発症した 3 名は 2001 年 9 月 7 日より 12 日ま で, オーストラリアで牛の屠蓄場および飼育農場 を視察し,その後 13 日にニュージーランドに移動 し同様の視察を行った後 17 日に帰国した。

症例 $1: 56$ 歳, 男性 (大阪府在住).

主訴：微熱, 全身倦怠感.

既往歴：特記事項なし.

現病歴および経過（Fig. 1）：9月20日頃 微 熱, 全身倦㤐感が出現, 職場の診療所を受診し抗 菌薬 cefteram pivoxil (CFTM-PI), 300mg/日,

別刷請求先：( ₹ 682-0951）鳥取県倉吉市津原 392-2 医療法人千希会河本医院河本 知秀 acetaminophen および carbocisteine の投与を 3 日間受けた. 28 日に 39 度台の発熱, 咽頭痛, 悪心 にて A 病院を受診し上気道炎の診断で抗菌薬 cefpodoxime proxetil(CPDX-PR), 総合感冒薬, loxoprofen sodium ならびに fosfomycin (FOM) $1.0 \mathrm{~g}$ の点滴治療を受けた。この時，血小板減少 $(9.2$ 万/ $\mu \mathrm{l})($ Fig. 2), 肝機能障害 (GOT: $59 \mathrm{IU} / l$, $\mathrm{GPT}: 69 \mathrm{IU} / \mathrm{l})$ (Fig. 3)，CRP $(8.0 \mathrm{mg} / \mathrm{dl})$ 上昇を 認めた。 10 月 2 日 40 度台の発熱, 全身倦怠, 悪心, 腹痛, 血压 $96 / 50 \mathrm{mmHg}$, 血小板 2.5 万 $/ \mu \mathrm{l}, \mathrm{CRP}$ $34 \mathrm{mg} / \mathrm{dl}$ と症状が悪化し $\mathrm{A}$ 病院へ入院した.この 時点で，上気道感染を契機に発症した特発性血小 板減少性紫斑病（ITP）を疑い，抗菌薬 piperacillin（PIPC） $4.0 \mathrm{~g}$ /日を 4 日間， $\gamma$ globlin $5 \mathrm{~g} /$ 日を 2 日間，およびステロイド剤 (methylprednisolone sodium succinate $1.0 \mathrm{~g} /$ 日）を投与した。抗菌薬は 10 月 5 日には panipenem batamipron (PAPM BP） $1 \mathrm{~g}$ /日に変更し，血小板の隇少に対し血小板 10 単位の輸血を行った。 ステロイド剤は 10 月 6 日には $0.5 \mathrm{~g}$, 同月 8 日には $0.25 \mathrm{~g}, 10$ 日には 0.125 $\mathrm{g}$ と漸減し，13 日には中止して経ロステロイド剤 (prednisolone acetate $20 \mathrm{mg}$ ) に移行した.

10 月 5 日に旅行の同行者二人も発症し同様の 症状を示していることが明らかになり，旅行中に 感染したことが示唆されたため，その後現地に問 い合わせて得られた情報から Q 熱を強く疑った。 11 日に, Q 熱の確定診断を国立感染症研究所に依 頼するとともに，Q熱に有効と考えられる MINO 
Fig. 1 Clinical course of case 1

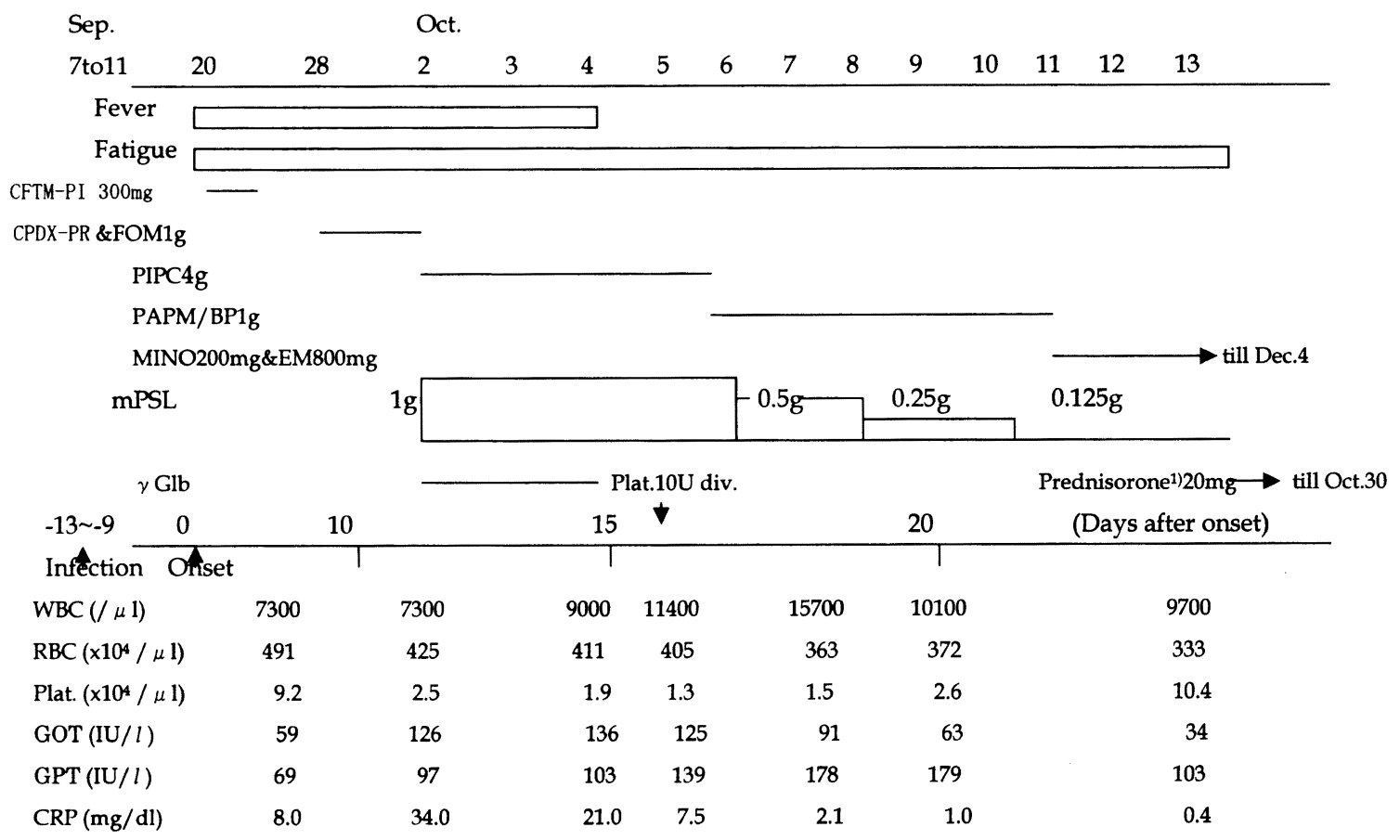

1) The dosage of prednisorone was $20 \mathrm{mg}$ from Oct.13 to Oct.15, $10 \mathrm{mg}$ from Oct.16 to Oct.23 and $5 \mathrm{mg}$ from Oct.24 to Oct.30.

( $200 \mathrm{mg} /$ 日) に, erythromycin ethylsuccinate (EM) $800 \mathrm{mg} /$ 日を追加して投与を開始した．血小 板は 1.3 万/ $\mu \mathrm{l}$ まで隇少したが, 10 月 9 日にようや く増加が確認でき, 10 月 13 日には 10.4 万/ $\mu$ lまで 回復した. MINO, EM 投与後急速に全身状態は回 復し 15 日に退院した. 退院後も, 12 月 4 日まで引 き続き MINO $(100 \mathrm{mg} /$ 日) と EM $(800 \mathrm{mg} /$ 日) の 投与を続けた.

症例 $2: 62$ 歳, 男性 (鳥取県在住).

主訴: 発熱, 全身倦点.

既往歴：心房細動，心不全。

現病歴および経過：10月 1 日 全身倦息, 筋肉 痛, 関節痛が出現，翌日 B 医院を受診した。体温 37.0 度, 顔面少し浮腫状であったが咽頭痛や咳な どの症状はなかった. Amoxicillin (AMPC) 750 $\mathrm{mg} /$ 日と総合感冒薬を 4 日間投与されたが，10 月 3 日には 38.5 度まで発熱し, 血小板の隇少 $(11.2$ 万 $/ \mu \mathrm{l})(\mathrm{Fig} .2)$ と肝機能異常 (GOT : 63IU $/ l$, GPT : $59 \mathrm{IU} / l$ ) (Fig. 3) を認めた。10月3日より
5 日まで lincomycin hydrochloride (LCM) 600mg/ 日の点滴静注を受け，9日には自覚症状は消失し た。他の症例と同様 $\mathrm{Q}$ 熱を疑い 11 日より MINO $(100 \mathrm{mg} /$ 日) で投与開始した. 心臓に疾患があるた め，心内膜炎を主訴とする慢性型に移行すること を懸念し，投与は 11 月 8 日 (4 週間)まで続けた。 確定診断は鳥取県衛生研究所と国立感染症研究所 に依頼した。

症例 $3: 54$ 歳, 男性（愛知県在住).

主訴：発熱, 全身倦意.

既往歴：肺炎 (平成 12 年).

現病歴および経過：10月 3 日夜 38.5 度, 全身倦 㤐感, 関節痛あり，6 日 C 病院受診し血小板減少 $(9.4$ 万/ $\mu \mathrm{l})$ (Fig. 2), 軽度肝機能異常 (GOT : 50 $\mathrm{IU} / l$, GPT $: 52 \mathrm{IU} / l)$ (Fig. 3), $\mathrm{CRP}(6.2 \mathrm{mg} / \mathrm{dl})$ の 上昇を認めた。咽頭痛, 咳などの上気道感染の症 状はなく，胸部レントゲン上でも異常を認めな かった。総合感冒薬および cefdinir (CFDN) 300 $\mathrm{mg} /$ 日を 4 日間投与された. 9 日には解熱し, 関節 
Fig. 2 Hepatic function in 3 cases

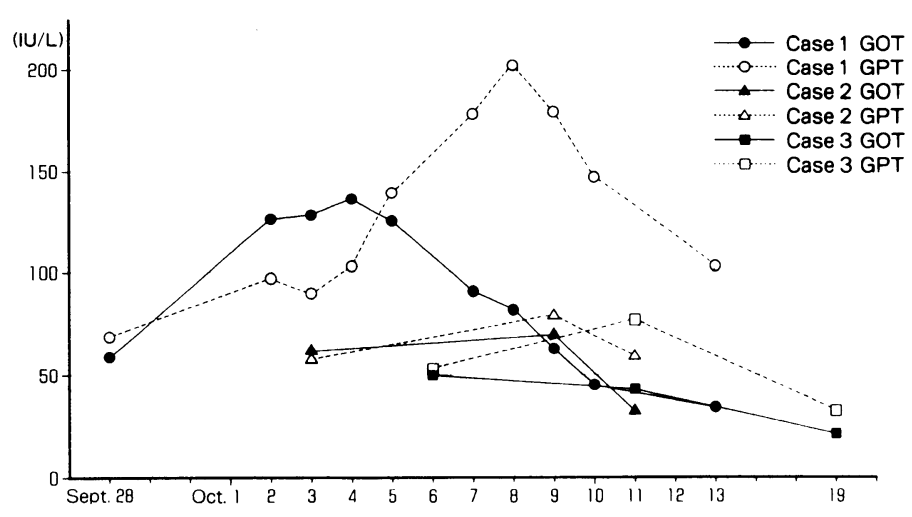

Fig. 3 Thrombocyte in 3 cases

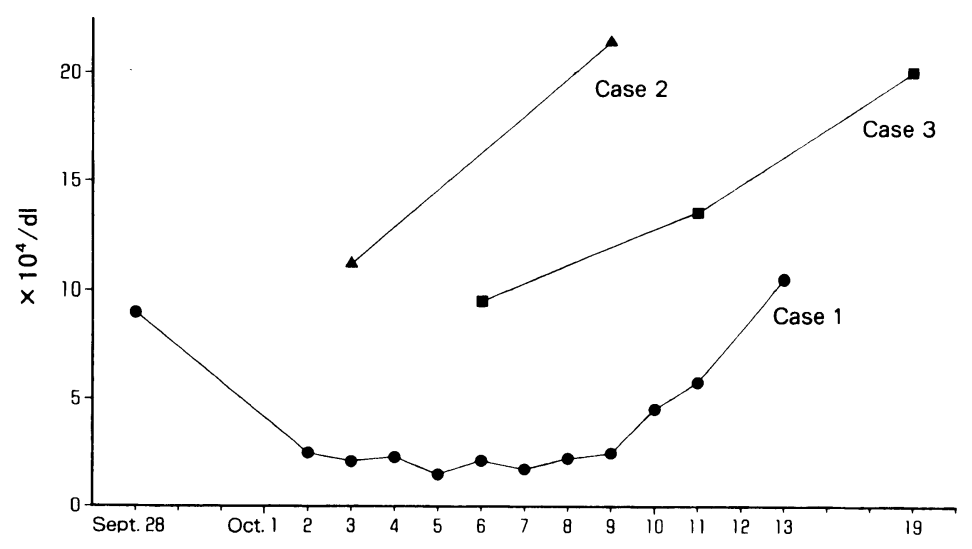

痛は消失したが全身倦㤐感は 13 日まで続いた. 11 日他の二人と同様に $\mathrm{Q}$ 熱を疑い, 確定診断を愛知 県衛生研究所および国立感染症研究所へ依頼する とともに, MINO $(200 \mathrm{mg} /$ 日 $)$ を 14 日間投与した. 19 日には肝機能異常も改善した.

実験室診断の結果 :

間接蛍光抗体法（IFA）を用いた抗体検査で，3 人の患者全てに急性期と回復期の血清よりC. burnetii II 相菌に対する 4 倍以上の抗体上昇がみ られた (Table 1).また, 症例 1 の急性期の血清か ら C. burnetii の遺伝子が検出された (Table 1). し かし, 症例 2 および 3 からは検出できなかった。

\section{考案}

今回の 3 症例は海外で感染した輸入感染症例で
あったが，輸入例を含めても国内で急性発症した 報告は少なく2131, 3 人同時に感染し発症した症例 の報告はなく，貴重な症例となった。

オーストラリアでは年間およそ 500 名の患者が 報告され，牛の屠蓄場での集団発生なども報告さ れている4. 一方で，ニュージーランドでは $\mathrm{Q}$ 熱 の発生が報告されておらず5, 今回の症例はオー ストラリアで感染したことが強く示唆された。旅 行行程では 9 月 7 日に屠蓄場を訪問して 2 時間程 度漁在した。その後オーストラリアでは牛の飼育 農場を 11 日までに 3 力所訪問している.Q熱の発 生が屠蓄場で多いこと, および症例 1 の発症日か ら考えると最初の訪問先の屠蓄場で感染した可能 性が最も高いと考えられた。 
Table 1 Antibody titers of the patients and gene detection by PCR

\begin{tabular}{lcccc}
\hline & & \multicolumn{2}{c}{ Antibody titer } & \\
\cline { 3 - 4 } & & Acute & Convalescent & \\
\hline Case 1 & $\operatorname{IgM}$ & 32 & 1,024 & + \\
& $\operatorname{IgG}$ & $<16$ & 512 & + \\
\hline Case 2 & $\operatorname{IgM}$ & 256 & 2,048 & - \\
& $\operatorname{IgG}$ & 128 & 512 & \\
\hline Case 3 & $\operatorname{IgM}$ & $<8$ & 1,024 & - \\
& $\operatorname{IgG}$ & $\mathrm{NT}$ & $\mathrm{NT}$ & \\
\hline
\end{tabular}

1) Serum-antibody titer against Coxiella burnetii phase II tested by IFA

2) Detection of C. burnetii-DNA from acute sera

NT: Not tested

潜伏期をみると, 症例 1 では 9〜13日, 症例 2 および 3 ではおよそ 3 週間であった。これまでの 報告では, $\mathrm{Q}$ 熱の潜伏期は一一般に 2 3 週間といわ れており ${ }^{\circ}$, 症例 1 ではやや短く,他の症例ではや や長かった. また, 症例 1 は他の症例と比較して 症状が重く, 急性期の血中から C. burnetii 遺伝子 が検出された。これらのことから, 症例 1 は暴露 された菌量が多かったため, 潜伏期が短く，また 重症度が高くなった叮能性が示唆された。

症状を詳しく見ると, 急性型 $\mathrm{Q}$ 熱には肺炎型と 肝炎型があるが，いずれも肺炎症状はなく，肝機 能異常と血小板の減少を特徵とする肝炎型であっ

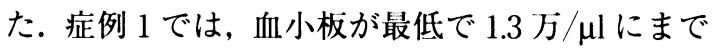
減少し，GOT および GPT は最高でそれぞれ 136 $\mathrm{IU} / l$ および $202 \mathrm{IU} / l$ になった. 今回の症例から重 症例では肝炎型であっても血小板の減少に対する 注意が必要であることが明らかになった。本邦で は $\mathrm{Q}$ 熱の不顕性感染の存在が明らかにされてい で, ペットや家畜などからの感染が推測されて いるが, 軽症例が多いためか急性期の明確な症状 が捕らえられていない。 今回の症例はいずれも発 熱, 倦䍐感, CRPの上年, 肝酵素の上昇および血 小板減少が見られ,これらが急性期 $\mathrm{Q}$ 熱の重要な 所見であることがあらためて示された。

治療に関しては, 症例 2 および 3 で $\mathrm{Q}$ 熱が疑わ れる以前に投与された AMPC, CFDNなどの抗菌 薬によって症状の改善が見られていたように思わ
れたが，Q熱が本来自然治癒傾向のある疾患でも あり，抗菌力の強い薬剤の投与がなくても症状の 軽快が見られた可能性はある．しかし $\mathrm{Q}$ 熱では慢 性化する症例があることが知られており，その予 防のためにも効果が明らかな MINOの投与が重 要であると考え, 本疾患を疑った時点でMINO に変更し投与を開始した。

また，今回の症例では，患者および現地からの 情報が，Q熱を強く疑うきっかけとなった，今後 は，上記のような $\mathrm{Q}$ 熱によく見られる症状がある 場合には, 渡航歴などを問診し疫学情報を得るこ とが重要であると思われる.

今回のように, Q 熱の実験室診断は, 国立感染 症研究所, 都道府県の衛生研究所などで可能であ るが, 病院や一般検查機関などの検査室では行っ ておらず検査体制が十分であるとはいえない。今 回のような重症例が今後も発生する可能性を考え ると簡易診断キットの開発など一層, 検査体制の 充実が望まれる.

\section{文献}

1）高橋 洋, 五味和紀, 菊池 楊, 渡辺 彰, 貫和 敏博： $\mathrm{Q}$ 熱による市中発症型呼吸器感染症の検 討. 日本化療誌 $1999 ; 47: 509$.

2) Oda $\mathrm{H}$, Yoshiie $\mathrm{K}$ : Isolation of a Coxiella burnetii strain that has low virulence for mice from a patient with acute $\mathrm{Q}$ fever. Microbiology and immunoloy $1989 ; 33(11): 969-74$.

3）宮下修行，深野浩史，原宏紀，原 史人，中嶋 健博, 二木秀人, 他：成人 Coxiella burnetii 肺炎の 一例. 日呼吸会誌 $2001 ； 39(6) ： 446-51$.

4) Gilroy N, Formica N, Beers M, Egan A, Conaty S, Marmion B : Abattoir-associated Q fever : a Q fever outbreak during a $Q$ fever vaccination program. Aust N Z J Public Health 2001 ; Aug 25 (4) : p. 362-7.

5) Surveillance (Wellington, N.Z.) : New Zealand is free from $Q$ fever. $2001 ; 28(4): 3-4$.

6）小川基彦：感染症の話 $-\mathrm{Q}$ 熱一, 厚生労働省・国 立感染症研究所 感染症情報センター 感染症 週報 2002:4(13)：9-11.

7) Kato K, Arashima Y, Asai S, Furuya Y, Yoshida $\mathrm{Y}$, Murakami M, et al : Detection of Coxiella burnetii specific DNA in blood samples from Japanese patients with chronic nonspecific symptoms by nested polymerase chain reaction. Federation of European microbiological societies immunology and medical $1998 ; 21(2): 139-44$. 
Three Imported Cases of Acute Q fever after an Inspection Tour to Australia and New Zealand

\author{
Tomohide KAWAMOTO"', Motohiko OGAWA"', Toshio KISHIMOTO², Yuichi UCHIDA ${ }^{3 \prime}$, \\ Katsumoto $\mathrm{KATO}^{4)}$, Ayumi KAWAMOTO") \& Teruo YAMASHITA ${ }^{6 \prime}$ \\ ${ }^{1)}$ Kawamoto Clinic, ${ }^{2)}$ National Institute of Infectious Diseases, ${ }^{3}$ Kyoritsu Hospital, "Koseiren Kamo Hospital. \\ ${ }^{5}$ Tottori Prefectural Public Health Laboratory, ${ }^{6}$ Aichi Prefectural Public Health Laboratory
}

After an inspection tour to farms and abattoirs in Australia and New Zealand, three Japanese persons simultaneously developed febrile illnesses in Japan. They generally had slight fever and general fatigue, followed by thrombocytopenia and hepatic dysfunction. However, no respiratory symptoms were observed. In one of the cases, severe thrombocytopenia $\left(1.3 \times 10^{4} / \mu \mathrm{l}\right)$ and high fever up to $40^{\circ} \mathrm{C}$ were observed. These clinical symptoms were compatible with $\mathrm{Q}$ fever. All of the cases showed four hold-elevations of $\operatorname{IgM}$ and $\operatorname{IgG}$ against Coxiella burnetii phase II between acute and convalescent sera by a serological test. C. burentii-DNA was also detected in the serum of one patient. Minocycline was highly effective in all cases. This report illustrates the typical clinical courses of acute $Q$ fever.

〔J.J.A. Inf. D. $76: 1030 \sim 1034,2002$ ] 